\title{
An epistemology of facilitation: A Julian Müller story
}

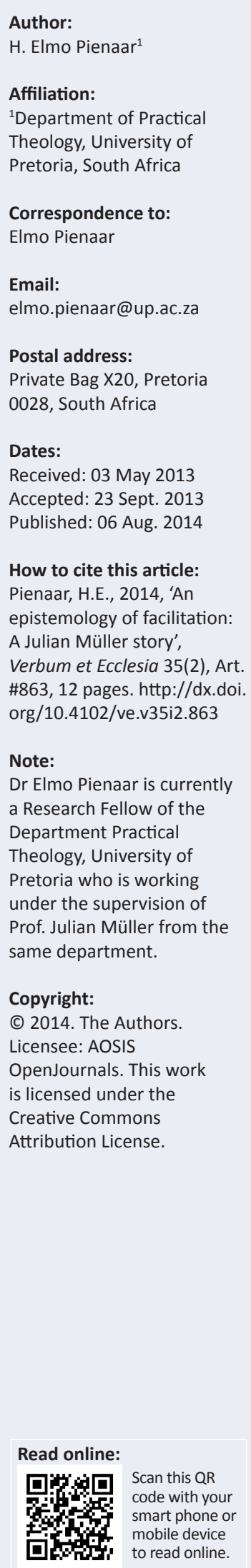

The article furthered an epistemology of facilitation. It was created through bringing into focus broad movements in Julian Müller's theoretical academic development. Rather than explaining at length the epistemological concepts characterising Müller's theoretical development - rightly because of the importance of narrative in Julian Müller's work - the article sought to link a social psychological dimension of both Müller and the author to these concepts. Resulting from Müller's work, the author regarded a narrative approach, social constructionism and postfoundationalism as important epistemological conversational partners in practical theological facilitation.

\section{Introduction}

An article such as this lends itself to a more personal touch, relating, in this instance, to the person of Julian Müller. ${ }^{1}$ I want to go one step further and draw attention to the social psychological (interpersonal) dimension of the academician in relation to his or her work. There is no such thing as a story - even, or perhaps especially, relating to one's academic positioning - without characters, places, experiences and events. It is my attempt to link the path of Müller's theoretical development to these. ${ }^{2}$ This means that the article is also, in itself, an expression of facilitation, as it brings together different people around things that count to them as significant conversations.

With this being the approach, it is also unavoidable that it would situate Müller's influence in the development of my work. Although Julian Müller has never actively, academically and otherwise, placed himself within a role of the facilitator proper as I understand it, his influence in character and his theoretical paradigms are acknowledged in the awakening of the peculiar animal I now nurture, that I have given the name of 'practical theological facilitation' (PTF). Some might reason that practical theology is already facilitative and, in terms of Müller's work, it may very well be. However, the facilitation that I have in mind, and this in relation to practical theology, involves more than using the description 'facilitation' in a general manner of speaking (cf. Pienaar 2012).

Julian Müller is one of a number of people to whom I ascribe having had significant influence in my life. Such influence is often the study of social psychology, inquiring about 'how the presence of others affects each person's thoughts, feelings, and behaviors, even if that presence is only implied or imagined' (Sternberg 2001:423). In related ways to Julian Müller having influenced me, there are those who, in turn, influenced Julian Müller with respect to the theories, ideas and concepts that one finds in Müller's epistemological semantic field. Notably these concepts involve a narrative approach, social constructionism and postfoundationalism.

Everything considered, the article seeks to call attention to an epistemology of practical theological facilitation, doing so in the process of following broad movements in Müller's theoretical development. It is therefore not an article that seeks to explain anew the notions of narrative, social constructionism and postfoundationalism.

My attempt is also not to reintroduce what I refer to as PTF; in this regard see Pienaar (2012) and Pienaar and Müller (2012). Nevertheless, I have to clarify at least this much. The idea of facilitation in PTF functions in a twofold manner. On the one hand, it is a metaphor, as used in the phrase 'practical theological facilitation'. On the other hand, I see it as a particular role ('facilitation proper' mentioned above; cf. Bens 2005:7-9), alongside other roles, such as, for instance, that of the pastoral therapist, the coach and a particular understanding of the consultant. I broadly view all of these, including facilitation, as 'helping relationships ${ }^{\prime 3}$ and, as such, they

1. Unless the context clearly dictates otherwise, all instances of the personal pronouns 'he', 'his', and 'him' refer to the person of Julian Müller.

2.In the space provided, and in view of other intended outcomes, I can only do this in a limited way.

3.Following Lawrence Brammer (see, for instance, The helping relationship, 1979) and Gerard Egan (see, for instance, The skilled helper, 2013). My treatment of these concepts is, however, situated in a vastly different epistemology than one would find with the both of them. 
form part of PTF. Used in this way, facilitation is situated in a professional community of practice. One such community of which I am currently a committee member in South Africa is the International Association of Facilitators founded in 1994 (Hunter et al. 2007:316).

\section{Progression of theory development}

In my view, Müller's academic development progressed naturally from the eco-hermeneutical theological point of departure to the narrative approach to postfoundational practical theology.

Owing to my consecutive studies, starting with my BA in Theology in 1995 up to the end of my PhD in 2005, I, along with some other students, became conversational partners and witnesses to how his thoughts would develop over the years. Tied to four phases of my own development, in my experience, his development progressed along the following lines:

- Phase 1: From the period 1995-1997 (during my BA Theology studies) to the period 1998-2000 (BD Theology), I experienced the shift from the 'eco-hermeneutical, narrative' Julian Müller, to the more pronounced 'narrative theologian' Julian Müller (cf. Müller 1994a, 1996; Müller \& Stone 1998).

- Phase 2: Starting somewhere during 1998-2000 (BD Theology) into the period 2001-2003 (MA Practical Theology), I experienced the pronounced shift from 'narrative theologian' Julian Müller towards a more articulated 'social-constructionist, narrative' Julian Müller (cf. Müller 2000; Müller, Van Deventer \& Human 2001).

- Phase 3: From roughly the end of the period 2001-2003 (MA Practical Theology) through the period 2003-2005 (PhD Practical Theology), I experienced the shift from the 'social-constructionist' accent in the narrative approach to the early influence of 'postfoundational theology' (cf. Demasure \& Müller 2006; Müller 2003, 2004, 2005; Müller \& Schoeman 2004).

- Phase 4: Then, from around 2003-2005 to the present, one could notice the maturing of his 'postfoundational practical theology' (cf. Müller 2009, 2011a, 2011b).

Naturally he will have his own account of his development, considering that his journey with practical theology in South Africa started already in the 1980s (Müller 2004:294). Whilst he was starting to contemplate practical theology, I 'contemplated' pre-primary school ... a humbling thought.

Going forward, it is important for the reader to keep in mind that many of the concepts are interwoven. Note that I have chosen what qualifies the three main headings on purpose, as a means of highlighting some of the woven strands:

- Narrative is deemed an approach. It is not just about telling stories in the same vein that other approaches might 'utilise' stories, irrespective of however important a function practitioners may ascribe to stories.

- The foremost aspect of social constructionism that I relate to facilitation is one of facilitation involving a worldview. It requires a shift in how one sees the world ... as constructed ... socially.

- The notion of postfoundationalism that particularly resonates with facilitation is one that emphasises conversation (which may, or may not employ narratives overtly). In the academic environment the conversation is notably an interdisciplinary conversation.

\section{A narrative approach}

I have never known a Julian Müller separate from a narrative perspective. To me, the narrative metaphor stands central to the person of Julian Müller. This is evident in his articulation of the importance of autobiography (cf. Müller 2011b). This is notwithstanding his preference for the comprehensive language that he sees postfoundational theology providing (Müller 2011a:2). Consequently, both under the sections relating to social constructionism and postfoundationalism, I direct attention to narrative aspects: in social constructionism, with reference to narrativity and narratology and, in postfoundationalism, with reference to autobiography.

Over the years Julian Müller's narrative approach would see different conversational partners. Some ideas and concepts would stay, whilst others would blend into the background.

\section{From eco-hermeneutics to narrative participation}

I first met Julian Müller whilst he was, in my experience, at a decisive turn from an eco-systemic perspective - more specifically a second order cybernetics perspective on pastoral family therapy (cf. Müller 1996:14) - on route to a more pronounced narrative theory and practice (cf. Müller 2000). In 1996, with Om tot verhaal te kom, his language still reflects part of second order systems thinking. This is noticeable in references such as the 'identified patient', 'circular story', 'circular causality' (Müller 1996:141) and 'eco-systemic story' (Müller 1996:159).

In relation to the eco-systemic one sees the development of an 'eco-hermeneutical paradigm' featuring strongly (cf. Müller 1994a; cf. Müller 1996:7-17). He says that in his article, 'Intercultural pastoral care. An eco-hermeneutical perspective' (Müller 1994a), he tried to unite the ideas of the eco-systemic and the hermeneutical intending to develop a theological frame of reference (Müller 2011a:1). Although many influences goes unacknowledged for being too many to mention, Müller (1996:foreword) dates what he sees as his first real awareness of an eco-systemic epistemology to 1990. Apart from extending gratitude to students in how his thoughts developed, he specially mentions that a colleague, Brain Childs, made possible a 3-month residency in 1994 at the Columbia Theological Seminary in Atlanta, Georgia, USA (Müller 1996:forward). This would see the birth of his 1996 publication Om tot verhaal te kom (Müller 1996:foreword).

For this article contribution, I revisited the said publication, which is, to me, representative of the Julian Müller I came 
to know during the first phase of my studies. It involves the 'eco-hermeneutical, narrative' Julian Müller. My emphasis herein falls on the narrative aspect. The reason for this is that the aspect of the eco-hermeneutical is said to lead naturally to narrative participation (Müller 1996:15; Van den Berg \& De Wet 2008). Progressively, so it did. In my experience, over the years he gained some distance from both the eco-systems and eco-hermeneutical language. ${ }^{4}$ It seemed unavoidable that he had to make a choice along the way between the metaphors of 'eco-systems' and 'storying cultures' (cf. Müller 1996:29); a choice between systems and stories.

\section{Revisiting the early narrative accent}

From this earlier contribution of Müller, there are two aspects that I see as important in the development of PTF. Firstly, is a focus on the past, present and future aspects of stories and, secondly, in the early narrative accent one finds a distinction he made between procedure and agenda.

\section{Emphasis on past, present and future}

The point of departure of a narrative anthropology lies in the unity of human experience (Müller 1996:20). Müller (1996:20) acknowledges Stephen Crites as amongst the first who noted that people experience their lives 'inherently in narrative form' (Crites 1971:291). The notion of time and unity refers to the aspects of past, present and future which I see as an accent in Müller's narrative understanding. It comes to the fore in both his 1996 and 2000 work. This accent is, for instance, different than following a narrative approach based on White and Epston's (1990) relative influencing questions wherein externalisation plays an important role. Although the notion of, for instance, externalisation is not absent from his 1996 and 2000 texts, the externalised story is only one procedure alongside many, specifically in his 1996 text. That is, it is not one of the broad movements that he sees as dancing between the past, present and future (cf. Müller 1996:104).

The narrative accent in the early Julian Müller has always meant a great deal to me in my personal-theoretical development. Considering that I emphasise a social psychological dimension, let me share something from my own story. Apart from that the telling of one's own story often renders one vulnerable, here it serves to illustrate how the theories we have an affinity for do not appear out of nowhere. Many times, most perhaps, there is some personal connection. This story also serves to illustrate how different stories, such as those of a personal, corporate, academic and theoretical kind, flow into and out of each other:

My first significant engagement with his 1996 text, as prescribed academic material, was at our family farm roughly 14 years ago. The title $\mathrm{Om}$ tot verhaal te kom is a good description for the kind of place that our family farm was for us to do just that ... particularly so for my father who grew up on the farm. Since then I have not been to the farm until recently. Once again the Müller of 1996 came along. But just as there have been considerable developments in our family over the past two decades, so have there been significant changes in Müller's

4.Van den Berg and De Wet (2008:149-159) track some of the developments that lead up to the 'eco-hermeneutical, narrative' accent in pastoral care. academic development. A considerable development in my own story is that fairly recently my father passed away. My father loved reading and during that farm holiday 14 years ago we would spend much of our time together reading. He would read some or other biblical-related text, language-related text, a musician's or composer's biographical sketch or other music-related work. ${ }^{5}$ I also, would read ... the work of Julian Müller. We would be interrupted almost exclusively by the wonderful smell of breakfast, dinner and supper ... the kind of mouthwatering smell that only a deep magic between an old coal stove and even older set of hands could conjure. As the days passed, Müller's academic text began to look, with all the highlighter markings, more like a Jackson Pollock ${ }^{6}$ - though not too abstract, but still - expressionist painting. It would be my father's second last visit to the farm and, in a good way, Müller's text marked that occasion. In the early morning hours 14 years later, April 2012, I would kneel with my mother beside my father's body on the carpet in the main bedroom of the house that saw my first steps in life. It was the exact bedroom that echoed my first baby cries. The last thing I did before his body was taken away was to unclip his watch from his wrist and put it on mine. It was surreal, like a Salvador Dali, to see the arm of the seconds-indicator on his Roman numeral ${ }^{8}$ watch still ticking ... ticking ... ticking into the future. From the watches that I own I mostly wear his. It is a reminder that the present is my time, as if he is saying to me 'live it fully'. There is more to this watch than meets the eye as there was more to many things that my father would purchase. For this reason, the watch is not just a call to live into the moment but a continuation of his story. In the weeks after his passing, I read up on the story of the company that started manufacturing watches in 1853, as displayed on its Roman numeral face. The watch manufacturer story had, in turn, lead me to read up on who the oldest watch manufacturing and other companies in the world might be. In conducting such spontaneous inquiries I realised that I was doing what my father had always done. Intellectual inquiry seems to have become our ritual. To him a piano was not just a piano. It has a name, it stands for something, it is made by a particular company somewhere in the world, in a particular way, to produce a specific sound, with specific wood and other parts. To own a piano did not just imply that music could or surely will be played but it also meant being part of music even if the piano is not played. During that time, after April 2012, I decided to return to the farm and when I did along came the Jackson Pollock that marked the history of the farm experience 14 years ago. It was most interesting to see how Müller's thoughts developed from that early text to where he is now. This article is part of that reflection 14 years ago and the more recent one on the farm to where my mind travels as I write. With the post-April 2012 farm visit, it is understandable that I had felt a deep sense of sadness: it was the first time that as my father's son I would enter that sacred ground without him, having to 'kom tot verhaal' without him. However, it was also the first time my father's grandsons would step into the sacred space of the family past and start writing a new story with their dad. They reached out even further into the past, the moment I realised with a great sense of legacy that they are running on the veld where my father's grandfather once walked about as a young man in what must have been the late-1800s. Their footprints changed the landscape, not so much of the farm, not so much of the past, but of the future. In all of this, the watch and the symbolic act of taking it from my father's wrist stands central. Adding to it the start of the development of a new story with my sons on the farm, the future story is carried into a rich present

5. He was a lecturer in music at the, now, 'School of Arts' of the University of KwaZuluNatal.

6.See his tribute website http://www.jacksonpollock.com/, viewed on 02 May 2013.

7.See the official website http://www.salvadordali.com/, viewed on 02 May 2013.

8.The Roman numeral system is often used in 'music harmony' (the subject of music harmony being father's forte). Most of my father's watches in the past had Roman numeral indicators. 
painting. Not always, but on occasion, reading time is a ritual that reaches into the past, as much as reading time is, on occasion, a silent performance of a new story extending into the future.

Thinking about this story, the reader will notice that there are many stories flowing into it. All these other stories have not been developed, but they are present still and still present. They relate to a watch-making company, a story about possessions such as the piano, of the painters Dali and Pollock whom I studied in art class many years ago, as well as a symbolic story of who or what I made these painters stand for and more. Each story has its own past, present and future and each one can be taken as entry point into other stories. Somewhere in all this is also the academic story, one that ties to Julian Müller, which, in part, finds expression in this article.

\section{Distinction between procedure and agenda}

Another reason I revisited Müller's 1996 text is that in Om tot verhaal te kom he follows a distinction between agenda and procedure (Müller 1996:98), a distinction he does not find value in upholding in Reis-geselskap (Müller 2000:68).

Although slightly different than in Müller's use, the distinction between process and content is one that is important in facilitation (Bens 2005:9), consulting (Burtonshaw-Gunn 2010:9; Cope 2010:170) and to some, narrative therapy (Freedman \& Combs 1996:44). Acknowledging that PTF has much to do with process and much less with content is to emphasise epistemology.

I cannot recall the date, but I remember having specifically asked Julian Müller about this: the development from making the distinction between procedure and agenda (Müller 1996:98) to following a more natural, or as he describes it, a 'method-less' approach that is, to him, in sync with the narrative perspective (Müller 2000:68). His view was that the concept of process comes across as locating the expert knowledge about process with the practitioner.

Where Müller decides to go method-less - in other words less reliant on methods and procedures - I decide to pause for a while. There is more to the facilitator's imperative regarding process than to relate it to the role of the convener, moderator, or chairman, or that even of a knowledgeable process expert. The idea of process can be placed within a modernist paradigm. Such a paradigm would cast the facilitator as the legitimate, perhaps unquestionable, voice on processes. Yet with the accent on the participative nature of facilitation another possibility might be to say, 'I have some experience and ideas to contribute but let's discuss it together.' The process might even change as the group deems necessary.

\section{Facilitation and a narrative approach}

From the above, the following comes naturally when acknowledging that a narrative approach forms part of the epistemology of facilitation.

\section{Soliciting stories}

A facilitator is a person who solicits stories. These involve stories about, for instance, a person's life, family, team, culture and organisation and how these might relate to each other. The stories might not only involve specific domains but particular themes, such as stories of performance, leadership and more.

There is also the possibility and importance of placing one's own story on the table as a facilitator (see section on 'Autobiography'). Müller has always offered stories and included reflections on experiences. ${ }^{9}$ This theoretical aspect of his work blends together well with postfoundationalism and the emphasis on autobiography (cf. Müller 2011b) (see section 'A postfoundational conversation'). I should at least mention that sharing one's own story, some would say, goes against the grain of conventional facilitation beliefs that uphold the facilitator as a neutral outside third party (cf. Kashtan 2005:573; Thomas 2010:240).

Not only does the facilitator solicit stories but he or she also tries to create as safe a space as possible for the telling and retelling of stories. If we are going to tell stories, certain stories in particular, it involves a great amount of risk. Müller knows from experience, having been subjected to controversy and its 'devastating' effects (cf. Müller 2004:297) that telling one's story can be a risky pursuit. He uses the expression of a 'safe but fragile' space. The notion of a safe but fragile space that postfoundationalism is believed to provide (Müller 2009:212, 213, 226, 2011a:3, 5, 2011b:3) is derived from Van Huyssteen (see, for instance, Van Huyssteen 2006:148).

To me facilitation is strongly called for, for a number of reasons:

- Facilitation is necessary as the kind of spaces that are required in which one can tell stories are not going to take shape by itself. In order for people to tell stories, it often requires more than an invitation to do so.

- The kind of spaces wherein one would want to tell stories are not necessarily safe. Consequently psychological safety needs to be facilitated. These spaces are perhaps often more fragile than safe. Although, bear in mind that when engaging in 'narrative logic' (through storytelling) it already offers more safety than 'decision-making' ${ }^{10}$ that is set within the framework of 'argumentative logic'.11 As a colleague, Chené Swart, said once regarding telling stories: 'There is nothing to argue about' (pers. comm., 03 December 2012).

9.By no means all instances: see Müller (1996:19-20) in terms of the aspects of experience and understanding in his Golden Gate National Park story, Mülle (2000:19-24) for a succinct account of his story being very much situated in the influence of the Africa context, Müller (2004), in part, related to having met Van Huyssteen in person and Müller (2011c) for the development of his faith and theological journey. For more on how to incorporate one's own narrative in formal scientific writing, see Nash (2004), Liberating scholarly writing: The power of personal narrative.

10.Being an important theme in facilitation (Bens 2005:7).

11.Müller (2011a) notes that the shift from 'argumentative logic' to 'narrative logic' is one that characterises our time, being a time of transition (see also Demasure $\&$ Müller 2006). This is also not dissimilar to the importance ascribed to the role of the imagination over the notion of objectivist morality and decision-making as primary pursuit or goal (Human, Liebenberg \& Müller 2001). 


\section{Facilitating unity between past, present and future}

What appeals to me particularly in this early conceptualisation of Müller's narrative approach (cf. 1996, but also 2000), is its accent on development through time. It draws on the understanding of stories consisting of 'events liked in sequence across time according to a plot' (Morgan 2000:5).

Müller aligns himself with various authors ${ }^{12}$ to articulate that a narrative approach is neither merely about the past, nor only about the future, when he situates them both as belonging to the present. Similarly to the 'one within the other' image of Russian dolls (Müller 1996:114), one might say that facilitation works with that which lapses from the past and the future into the present (fn. 12).

As my perspective on facilitation shares the epistemology of a narrative approach, the following points are also the task of the practical theological facilitator. It is therefore not only relevant to the context that Müller writes about, for a person or family undergoing therapy. Adapted from Müller (1996:104; cf. Müller \& Stone 1998:331) to refer to any individual, team or group, or organisation (ITO) the task of the facilitator is to:

- Facilitate the telling of the immediate story and the significance of the reason for meeting. This may involve a story of distress, of stuckness, of a particular barrier that the ITO is experiencing and so forth.

- Facilitate the ITO in telling the story of the past.

- Facilitate the ITO in telling the future story, so that the nature of the obscured future becomes known from the past story.

- Facilitate the reframing and reformulation of the ITO's past story.

- Facilitate the reconstruction of the future, with the aid of the imaginative capacity of the ITO.

\section{A social-constructionist worldview}

Somewhere in-between the development from the ecohermeneutical to the postfoundational, one finds the Julian Müller who conceptually influenced me most, namely, one who positioned himself strongly within a social-constructionist, narrative view. I situate the socialconstructionist accent in Müller's narrative understanding particularly in the second to the third phase of my studies - in other words between 1998 and 2003. A notable research project on HIV and AIDS, following this social-constructionist narrative accent can be read in one of his articles (cf. Müller 2003).

He indicates that when he travelled to the USA in 2003, he attended a conference and workshop in narrative therapy which served 'again, [to expose him] to the ideas of socialconstructionism as the basis of the narrative approach

12.In respect of the notion 'lapsing into the present' (Keith \& Whitaker 1988:440; cf. Müller 1996:110). In respect of the 'human sense of time extending in three c. Muller 1996:110). In respect of the "human sense of time extending in thre directions or dimensions, namely, past, present, and future that establishes the prest (lil present and the future as already-present' (Niehbur 1963:92; cf. Müller 1996:114) In respect of 'the present-past, present-present, present-future ordering everyday praxis' (Gerkin 1986:51 following Paul Ricoeur; cf. Müller 1996:207). to therapy' (Müller 2004:297). At that time, many of the postgraduate titles would start with, 'A social-constructionist understanding ...' or 'The social construction of ...' My article, based on my Masters degree research co-authored with Müller read no different (the ordering of words is indicative of the particular accent at the time): 'A social-constructionist, narrative understanding of the Church's morality on sex' (Müller \& Pienaar 2003). It was also in 2003, parallel to being strongly informed by social constructionism, that Müller's interest in the postfoundational perspective gained significant impetus through having met Wentzel van Huyssteen (cf. Müller 2004:298).

The reader might want to ask why, in this section, I continue with the concept of stories. This is because Müller's differentiation between how people do different things with stories has everything to do with social constructionism. In other words, the way that Müller views stories, reflects this social-constructionist accent in his work. In contrast, many of the ways in which stories might be put to use are far removed from the epistemology of social constructionism. For a more overt explanation of social constructionism, the reader might want to follow up on Gergen (1999) and Burr (2003).

\section{Narrativity and narratology}

Müller's understanding of the narrative metaphor is thoroughly undergirded by a social-constructionist view of reality. It is this view that distinguishes the way that Müller sees and uses stories from other ways. Although Müller always made it very clear that people do not think about stories in the same way, he did not always use the terminology that I've heard him use over the past few years. In conversation, he would start to draw a distinction between 'narrativity' and 'narratology' as technical terminology. Until recently, he has not furthered this distinction officially. Unofficially, he used it in a University of Pretoria continuing education course in 2011 that we co-lectured entitled, Management: The narrative way. Of late, he has officially done so in both his University of Pretoria 'expert lecture' (Müller 2012b) ${ }^{13}$ and in a commemorative publication to a former colleague (Müller 2012a:95-105).

Without such a distinction, it is important to establish from what worldview or epistemology a scholar writes. If it is not decidedly from a dialogical-relational, cultural-linguistic, evolving, holistic, social-constructionist perspective, then chances are that it is being used from a narratological perspective. A narratological treatment of stories does not rhyme with that of the tradition wherein Müller stands. The closest that I came to a distinction of how stories are used differently was with my PhD research (Pienaar 2005) leading me to consider that there is a difference between 'narrative as' art, therapy, or organisational work (i.e. narrativity in Müller's language) and 'narrative in' art, therapy, or organisational work (i.e. narratology).

13.In the introduction of the 'expert lecture' series, Müller (2012b) light-heartedly refers to the irony of giving a so called 'expert lecture' on the markedly narrative concept of a 'not-knowing' position (Freedman \& Combs 1996:44). 


\section{Narrativity}

Müller's approach to stories (i.e. narrativity) sees as a metaphor the way in which one might understand reality (Müller 2012a:103). It relates to the arts and, in this, a holistic understanding of stories as a form of art (cf. Müller 2004:293, 2012a:103). He ascribes his holistic understanding particularly to his Africa influences, the latter of which holds a holistic view of theology and science in general (Müller 2004:294).

The seminal work of Freedman and Combs (1996) was, at one stage, required reading and the title concisely voices Müller's understanding: Narrative therapy. The social construction of preferred realities. The main idea is that stories are constructed, they are the shaping of reality, much more than they are told as if they exist somewhere in a ready to deliver format. Taken to its full measure - although it does not wish to be relativising in the sense that it would hold that 'anything goes' (Freedman \& Combs 1996:35) - social constructionism leaves no stone unturned and offers strong challenges to any kind of absolutist or essentialist reality discourse. This is evident in what Freedman and Combs (1996) say about the views of Anderson and Goolishian, who they see as postmodernists through and through:

Anderson and Goolishian ... do not believe that the 'unsaid' is something that already exists. It is not lying hidden in the unconscious or waiting, fully formed, to be noticed and described in the cybernetic structures of family interactions. Rather, it emerges and takes shape as we converse with each other. (p. 45)

In part, such strong voices relate back to the postmodern conversation. Müller (2005:8) rather opts for a postfoundational perspective. The latter, he says, 'helps us to better position ourselves against the relativistic tendencies in some approaches within social constructionism and the narrative approach' (Müller 2005:8). Initially, Müller (1996:32) viewed social constructionism outright as belonging to postmodern theory. From Müller (cf. 2005:8), it is clear, however, that social-constructionists could have 'tendencies' that might see them situated in degrees of Postmodernism.

\section{Narratology}

Müller (1996:20, 2004:293, 2012a:103) does not view stories, as is the implication with narratology, as objectifiable phenomena that need to be analysed and interpreted. Narratological approaches use stories from a structuralist and analytical perspective (Müller 2012a:103). Sometimes it is referred to as 'narrative analysis'. See, for instance, Roesler (2006) working with 'archetypical story patterns' and Oliver (1998) for whom narrative analysis is a journey of 'discovering meanings', instead of how Müller would see it, one of 'constructing meanings'.

What could also be confusing is the use of 'discourse(s)', which is part of the language of, especially, 'macro social constructionism' (as opposed to 'micro-'; Burr 2003;
Demasure \& Müller 2006), considering there is also the idea of 'discourse analysis' (Johnstone 2008). Johnstone (2008:3) draws attention to discourse analysis and how proponents of Michel Foucault would use discourse in a 'related but somewhat different' sense. The epistemology of PTF is more aligned with Foucault's understanding of discourse and one can scarcely omit acknowledging in the matter of discourse Jacque Derrida and his notion of deconstruction. ${ }^{14}$

\section{Facilitation and social constructionism}

Epistemologically, the concept of facilitation relates most clearly to social constructionism (and, at first blush, less overtly to narrative and postfoundational thought). Müller (1996:13) remarks that Rosenbaum and Dyckman (1995:33) said that the epistemology of the ecosystemic is empty. This is a good way of describing facilitation as it relates to social constructionism also. The epistemology of facilitation is one that is empty. If it is not empty, then one can perhaps speak less of the art of facilitation because it could be seen to border on the 'the art' of manipulation. What I refer to as manipulation relates to the aspect of politics in facilitation (see Drennon \& Cervero 2002; Kirk \& Broussine 2000). The 'emptiness' refers to the space wherein something is collaboratively created, not only in an interpersonal sense but also culturally.

The facilitator working from a social-constructionist perspective would call attention to two things. Our current realities are constructed. In similar vein, our future realities are currently under construction. The facilitator would work in ways that deconstruct 'factivity' and, in so doing, create awareness around the factified ${ }^{15}$ nature of what we take for granted as true. To my mind, one should be wary of saying that one or even a few instances of therapy, facilitation, coaching, and so on, count as social-constructionist processes. Where one would stand on this is influenced by where one places the accent in constructionism ${ }^{16}$ : within the social psychological and interpersonal sphere, or in the domain of the shaping of societal and cultural discourses. ${ }^{17}$

\section{Facilitation, social constructionism and their narrative affinity}

Freedman and Combs (1996:22) call attention to a few meanings when locating the kind of work they do within a postmodern worldview, one of which is the acknowledgement that our realities are 'organised and maintained through narrative'. The importance of 'narrative' features strongly in social constructionism, as it relates to the idea that our realities are foremost linguistically shaped. The facilitator needs to engage the ITO in 'storying' practices $^{18}$ towards developing preferred realities.

14.For Foucault and Derrida in relation to the narrative metaphor, see White and Epston (1990) and Freedman and Combs (1996).

15.I am following the distinction of Arbnor and Bjerke (2009) between a 'factive' and 'factified' reality.

16.Note, not 'constructivism'

17.For more on specifically how reality is shaped socially over a period of time, see Freedman and Combs (1996:23-27), who succinctly follow Berger and Luckmann (1966). See also Arbnor and Bjerke (2009:144-148) relating to the creation of business knowledge.

18.Differently stated: 'performance of stories' (Freedman \& Combs 1996:87-88) 


\section{Facilitation apart from stories}

The practical theologian, operating in a professional public capacity, will not always have the freedom to follow a very pronounced narrative methodology. The question then in consideration is how a social-constructionist methodology might look ${ }^{19}$ The kind of expression of rationality that characterises some businesses will make this almost impossible to do. Also, in this sense, the person of the practical theological facilitator facilitates in the 'ecotone' ${ }^{\prime 20}$, where different shapes of rationality present themselves and not just the kind that share similar epistemic values.

If the facilitator were not to ask for stories or experiences of the ITO, or elaborate through purposeful story development, there are still a number of things to which he or she should try to give expression or raise awareness. According to Harsch-Porter (2011:82), these relate to three characteristics that social-constructionist theories share, (1) knowledge is communally created, (2) personhood (self and identity) is created within relationship and (3) language creates our world.

A few question examples from Harsch-Porter (2011:83) that underscore social constructionism taken from the context of coaching for 'effective leadership' are:

- How do you define being an 'effective leader'?

- How is this defined in your organisation?

- Could it be defined differently in other organisations or other parts of your organisation?

- Who will evaluate and decide?

- How will it be measured?

- What or who might resist your being an effective leader?

- How have others gone about becoming viewed as more effective leaders?

The point here is that these questions do not rely outright on the notion of story. Instead, the focus lies elsewhere with creating awareness around the idea that what is understood as effective leadership is a construction. Even with the last question, which would quite possibly lead to telling stories, it does not necessarily entail that such stories are going to be put to use in creating a unity between past, present and future.

For the facilitator who aligns his or her approach with social constructionism (in addition to purposefully working with stories), rituals, symbols and metaphor are also important. Grözinger (2012:40) asserts that for the act of interpretation we rely on symbols, stories and rituals. Freedman and Combs (1996:1-2) write about the effect of using certain metaphors for how we approach our work with people. White and Epston (1990:6) have much to say about different analogies (still, 'metaphors' as understood from a cultural linguistic perspective) in science and how as a result of this we see what constitutes problems and solutions in different ways and with different effects. In relation to the organisational context, see Morgan (2006), Images of organization.

19.cf. Holstein and Gubrium's (eds. 2008) Handbook of constructionist research.

20.See Müller (2011a:4, 2011b:4) for how he uses the concept.
The task of the facilitator aligning himself or herself with social-constructionist thought, in addition to nurturing storying spaces, purposefully facilitates the act of collaboratively interpreting the symbols, rituals and metaphors ${ }^{21}$ relevant to the individual, family, group, team, department, organisation, culture and society.

The idea that reality is factified (in other words, socially constructed), moves facilitation 'beyond structuralism and also beyond constructivism' (cf. Müller 2004:298, writing in respect of social constructionism). The reason for this is that if social constructionism is thoughtfully considered, it 'corrects the subjective, individualistic, and intra-psychic ideas on the construction of realities within constructivism' (Müller 2004:298). It is furthermore 'a protest against relativism and an emphasis on the value-driven processes through which preferred realities are socially constructed' (Müller 2004:298-299).

\section{A postfoundational conversation}

In the same year that Julian Müller was exposed again to the social-constructionist ideas informing narrative therapy, he returned to the USA, where he met Wentzel van Huyssteen at Princeton (Müller 2004:298). He notes that he had read earlier work of Van Huyssteen before meeting him in person (Müller 2004:298).

It was around 2003-2004 that my PhD studies commenced. I recall that it was a consideration for students whether they would follow Müller's narrative research movements of an 'ABDCE' approach (action, background, development, climax and ending) (cf. Müller 2003; Müller, Van Deventer \& Human 2001), which was what I chose to follow, or Müller's then maturing postfoundational approach to research. It was clear to me that the Julian Müller of my PhD studies was largely situated in what he had developed along the lines of Wentzel van Huyssteen's postfoundational theology. He adapted Van Huyssteen's postfoundational ideas for practical theology with great proficiency, referring to it as postfoundationalist practical theology (Müller 2004:300 and, in similar fashion, cf. 2005).

\section{Contributing factors to theory development}

From Müller's writings, it seems that there are at least three elements that informed his development as an academician.

\section{A conceptual fit}

He shares one of the reasons why, to him as a practical theologian, he finds postfoundationalism appealing:

Practical Theology is the one theological discipline that can never afford to be detached from basic forms of theological reflection. This is precisely the reason why I find the concept of postfoundationalist Practical Theology such a valuable contribution for the understanding of Practical Theology. It

21.In the organisational context, these may well be and involve graphs, figures, or financial statements; that is, as symbols, rituals, or metaphors. 
constitutes a re-discovery of the basic forms of Practical Theology. It is an effort to move beyond the modernistic boundaries of Practical Theology, which tends to be formal and rationalistic. On the other hand, it is also an effort to avoid the relativism of antifoundationalist theories, which are a real threat to Practical Theology. (Müller 2005:2)

\section{A personal touch}

One should not miss the fact that, in the spirit of postfoundationalism, his journey with postfoundationalism gained great impetus from the very specific or local context of having met Van Huyssteen. It is as embodied as one can get - and good-humouredly, of course the special single malt whisky played its part (cf. Müller 2004:298). He gives the following account of his meeting Van Huyssteen:

After I have settled into my apartment in Payne Hall, I discovered that Wentzel and his wife Hester were my immediate neighbours. They welcomed me with friendship and hospitality and we enjoyed numerous social interactions. We shared a number of likes and dislikes. Wentzel shared some of his precious single malt whisky with me and we went to the movies and discussed theology for hours on end. (Müller 2004:298)

To a lesser degree I would say, but in related fashion his in-person experiences with those he refers to, in inverted commas, as the 'gurus' of narrative therapy (Müller 2004:297), undoubtedly provided momentum for the development of the narrative metaphor in his practical theology and research at a certain stage in his life. These gurus are Michael White, Jill Freedman and Gene Combs whom he met on various occasions (Müller 2004:297). He shares, for instance, that a workshop he attended, which was facilitated by Jill Freedman and Gene Combs, was an inexpressibly rich experience (Müller 2011b:2). It was the first time he was guided and consequently able to externalise and reflect on his theology (Müller 2011b:2). He particularly mentions how he discovered that his theology was part of his life story (Müller 2011b:2).

The strength of attraction to a theoretical framework is undoubtedly influenced by one's own story. Even more so, I would say in instances where there has been significant personal contact with the people one encounters in our stories. There is therefore a strong story-person-theory link. Müller, for instance, acknowledges in aesthetic language that he discovered the 'beauty of a postfoundational understanding of theology' through personal contact with Wentzel van Huyssteen (Müller 2011a:1). In terms of Müller's academic development and affinity to theories, I would reason that the idea of 'knowing' (a person or theory) would have significantly different meanings in relation to different people and theories. The content of the word 'knowing' would not match up when comparing knowing Wentzel van Huyssteen (postfoundationalism), versus knowing Jill Freedman, Gene Combs, or formerly Michael White (narrative approach), versus knowing the major contributors of a theoretical framework only at a distance (such as Kenneth Gergen regarding social constructionism).

\section{A healing moment}

I think there is at least one other reason, derived from a social psychological reading, that - to a degree that I cannot decide on Müller's behalf - caused the postfoundational view to flourish as it did from 2003 to present. This surely has to do with having met Wentzel van Huyssteen in person, but more so with having met Van Huyssteen at a particular point on Müller's journey.

His acquaintance with Van Huyssteen came at a time when he had a very unpleasant experience at one of the church denominational synods in South Africa (cf. Müller 2004:297298). He says that he was 'confronted with a fundamentalist hard-line approach' and he acknowledges that he felt devastated (Müller 2004:297).

\section{Autobiography}

One of the very exciting developments in terms of the recent Julian Müller is, to me, the shift to a focus on the practical theologian more so than on practical theology as such (Pienaar \& Müller 2012).

It needs to be emphasised that autobiography, which Müller (2011b) writes about in '(Outo)biografie as teologie', is located still in what he refers to in his article, 'Postfoundational practical theology for a time of transition', as the 'shift of emphasis from individual to social, from subjective towards discourse' (Müller 2011a:3). These shifts constitute a 'new epistemology in the social sciences' which he sees as part and parcel of the postfoundational movement (Müller 2011a:3). Autobiography is therefore not individualistic and cannot be relativistic if approached authentically. And with this being the case, the topic of autobiography fits with the heading of a postfoundational conversation because it is particularly in this kind of conversation (not the individualistic or relativistic kind) that one's own story can be raised.

I find the treatment of autobiography in Müller's epistemology highly relevant in my development of PTF. It provides a thoughtful answer to two seemingly unrelated audiences. The business audience might want to know what the 'business' of practical theology is in the economic and management sciences. Likewise, practical theologians might, at first glance, wonder what their theological discipline has to do with the business environment.

The narrative autobiographical voice will hold that there is no easy answer or principle in the above matter other than that the practical theological facilitator has a story that connects these fields. Credibility starts here. It is the sharing of the story in the public organisational space that takes practice, what should really be described as practice orientation, one step further to practice participation. That is why narrative social-constructionist research is, to me, an expression of practice participation. I think that many forms 
of research in practical theology could almost exclusively be seen as practice orientation. The reason for this is because it still offers little more than a theoretical perspective on practice. However needed and relevant, practical theological facilitation prizes practice participation, whether in research or formal facilitation, counselling, or coaching.

Putting forward one's story as the starting point of credibility in different domains is a difficult but honest position to hold. It is difficult because it knows that it cannot rely on universal theological principles or other discipline's qualifications for the credibility of the practical theologian who engages the organisational context in practice. As such, one's theology is an extension of one's narrative and not the other way around. Behind and informing the well-received theories and work of esteemed academics (from historians, psychologists, to neuro-scientists) and notable public advocates, lies the personal story of a human being situated in time and space, events and characters.

To me, as to Müller, if one was to be honest and realise the influence of and the way in which we continually construct our autobiographies, it implies a shift from practical theology to the practical theologian (Pienaar \& Müller 2012). Consequently, it is not only the stories of those we journey with that are important but also the local and contextual nature (the narratives) of the practical theologian's practical theology that matters (cf. Müller 2005:12).

In recognition of the importance of shifting attention to the person of the theologian, in a recent article, Müller (2011b) reflects on the relationship between autobiography and theology. He shows affinity for aligning practical theology with the pursuit of ethnography, especially in terms of it being an act (Müller 2011a:4; eds. Ellis \& Bochner 1996). Our autobiographies ('self-stories') tell of us, situating who we are as practical theologians, acting (i.e. practice participation) in the world. In their landmark publication on narrative therapy, Freedman and Combs (1996:1) refer to Ralph Waldo Emerson as having said, 'There is properly no history; only biography.' Relating to this in some respects, I share Nash's (2001) opinion which is also relevant to science and practical theology:

My own spirituality of teaching is a variation of the postmodern assertion that, at some level, all theory is autobiography. I believe that teaching, like religion, is really autobiography, a highly personal narrative that the believer creates in order to elicit, and to answer, the most confounding existential questions, the ones that defy easy scientific, political, or technological answers. (p. 8)

Müller's theology also stands in opposition to the easy answers that any domain, such as science but particularly theology, might offer. These easy answers, to my mind, can come from both fundamentalism and Postmodernism. Müller's theology is a theology of doubt; doubt as a metaphor for doing theology (Müller 2012b). His theology is removed far from fundamentalism (foundationalism) but is also not a theology of relativism to where Postmodernism might lead. The metaphor of doubt stands opposed to viewing theologians as 'the champions of certainty and elite' (Müller 2012b:n.p.). Müller (2012b) says that:

... the more you dwell in the vicinity of the ultimate questions in life, the more likely you are to become disoriented. Such disorientation, however, is a prerequisite ... for the reaching of new orientation. (n.p.)

He acknowledges the influence of Walter Brueggemann (see also Louw \& Müller 2002) in this idea.

I believe that this autobiographical (self-narrative) development in Müller's career is an important one. It moves beyond using stories as narratological devices (a place he was never at), even beyond developing stories of others, towards constructing preferred realities, to taking seriously one's own story in the moving in and out of the stories of our memberships in life, culture, theology, organisations and so on. In this sense, practical theology becomes part of different stories as an interdisciplinary partner to a postfoundational conversation. This kind of practical theology has two focal points: the local and contextual and postfoundationalist theology (Müller 2005):

This practical theological narrative is not only a paradigm-story, but also a method-story. It is an integrative narrative, which allows the practical theologian to participate in processes of both 'story-telling' and 'story-development', with integrity. Therefore it is a Practical Theology that is sensitive, descriptive, but also bold in its deconstruction of negative discourses and in its development of new alternative stories. (p. 12)

\section{A postfoundational link with the narrative approach and social constructionism}

Although Müller prefers the comprehensive language of postfoundational theology (Müller 2011a:2), this should not be taken to mean that he has abandoned the socialconstructionist narrative perspective. In fact, as indicated earlier, it seems that the aspect of story, through his recent writing on autobiography (cf. Müller 2011b), has received new impetus.

To him, the narrative does not only make sense in the postfoundational approach but is indeed inevitable (Müller 2011a:2). It is inevitable in the sense that, 'the postfoundationalist approach forces us to listen firstly to the stories of people in real life situations' (Müller 2011a:3). This also closely resembles what he says about the socialconstructionist approach (Müller 2004:295). The link that Müller sees between postfoundationalism and narrative is furthermore evident in an article he co-authored with Professor Demasure. They point to what they see as a narrative turn in pastoral care, evidenced from 'three different supporting perspectives', namely, Paul Ricoeur's hermeneutics, social constructionism and a postfoundational practical theology (Demasure \& Müller 2006).

Specifically with regard to social constructionism, there is, in Müller's mind, no doubt that socially constructed interpretations and meaning are part of the postfoundational approach (Müller 2004:299, 2011a:3). He recalls from 
conversations with postfoundational theologian, Wentzel van Huyssteen, how postfoundationalism reminded him of social constructionism in that, as with postfoundationalism, 'social-constructionism is an effort to come to a more balanced and viable epistemology after the cul-de-sac that resulted from some postmodernist approaches' (Müller 2004:298).

\section{Facilitation and postfoundationalism}

Van Huyssteen (1997:4) sees postfoundational theology as making two moves: on the one hand it acknowledges contextuality, but on the other hand it reaches beyond the local context. It seems that the most fruitful postfoundational conversation will be those where participants agree on the assumptions of postfoundationalism. I derive the following, what I refer to as assumptions, from Van Huyssteen's (1997:4) description of the above mentioned two moves:

- Experience is always interpreted.

- Tradition plays an important role in shaping the epistemic and non-epistemic values that inform our reflection (in the religious context particularly our reflection about God and God's presence in the world).

- The claim is made in a postfoundational notion of rationality that reflection 'points creatively beyond the confines of the local community, group, or culture towards a plausible form of interdisciplinary conversation' (Van Huyssteen 1997:4). In other words, it is the postfoundational notion of rationality that allows us to have a 'democratic presence' and thus a voice (Van Huyssteen 2000:437, 2006:147).

Leaning on a facilitation perspective, where the emphasis is on practice participation, the aspect of postfoundationalism that I would like to underscore is that of being a particular kind of conversation. Müller (2009) illustrates part of this conversation within the broader postfoundational movement, showing that transversal rationality can be a practical way of guiding an interdisciplinary discussion. From this contribution, it becomes clear how the researcher acts as a facilitator by calling on participants to reflect from various perspectives on a specific context.

It is interesting to note that he uses the word 'facilitation' and ascribes responsibility to the researcher - I see it as relevant to the facilitator also - for generating empathetic reflection (Müller 2009:226). Speaking about his role:

If I had formulated the question [to the interdisciplinary research participants] around Sizwe's own concerns [relating to the story of the research subject], I would have been more in line with the philosophy of transversal rationality. I could have created a higher degree of transversality by facilitating a mode of empathetic reflection on Sizwe's situation, and it would have been a logical consequence of transversal rationality. (Müller 2009:226)

Please note that empathetic reflection, which is also the task of the facilitator, does not mean that participants in the postfoundational interdisciplinary dialogue should have, or reach, consensus. This is also true of facilitation (Hunter et al. 2007:106). To the contrary, many facilitators will agree with Van Huyssteen (2006a:33): dissensus is a positive and constructive part of pluralism. Van Huyssteen (2006:148) rather speaks of creating optimal but fragile communal understanding that he believes we are capable of at any given moment in time. The facilitator goes accord.

These and other matters concerning postfoundationalism are quite congruent with my understanding of facilitation. Still, here are some of my views on why facilitation is a necessary adage in epistemology involving a narrative approach, social constructionism and postfoundationalism:

- I see the need for facilitation in the idea that such a conversation (postfoundational or any other) is not necessarily going to take place by itself. One of the assumptions about people and therapy from a narrative perspective is that people seek therapy 'because they are struggling with a dilemma for which the kind of conversation needed for its resolution cannot occur' (Freedman \& Combs 1996:273). With minor adaptation this is par excellence the role of the facilitator in respect of the ITO. It is for the acknowledgement of - what postfoundational language refers to as - 'degrees of transversality' (Müller 2011a:4) that facilitation is necessary. The critical conversations are not always going to take place across disciplines or in organisational life as though they might more naturally if sharing the same epistemic values. Even if sharing the same epistemic values, it involves a 'deliberate' (again underscoring the need for facilitation), stepping over one's own safe disciplinary boundaries.

- Since I have started to nurture these ideas, I became aware, particularly amongst practical theological colleagues, how often they use the word 'facilitation'. Van Huyssteen, it seems, also finds it necessary to use the word facilitation at times (Pienaar \& Müller 2012:2). If we cannot stay away from the idea that something needs to be facilitated, then there is perhaps more to be said for the importance of the role of the facilitator in the kind of conversations that we deem necessary. Müller (2011a:1) mentioned that since being involved in teaching full time from 1990, he had the growing need to not 'teach' narrative therapy but rather 'convey' what narrative is about in both the content and method of his teaching. Apart from him, at times, putting to use the word facilitation and adding to his earlier need to exhibit a specific teaching style, it again strengthens the need for what the role of the facilitator is about. His abovementioned need to 'convey' has, in my view, much to do with 'learning facilitation' ${ }^{22}$

- The postfoundational conversation should also be one that is to be had outside of the academic interdisciplinary environment. Both Van Huyssteen and Müller's treatment of postfoundationalism is largely situated in the academic context. References that markedly emphasise interdisciplinarity in postfoundational language do the same (cf. Van Huyssteen 2000). For PTF, however, both the public and academic audience is important. Rightly, because Müller is a practical and pastoral theologian

22.Showing towards different purposes of facilitation (cf. Pienaar \& Müller 2012:6) facilitation as effective form of adult learning (Hiemstra 2012). 
and underscores this approach to research, he gets much closer to the kind of public concerns, not detached from the academic audience, wherein facilitation could have particular relevance.

\section{Conclusion}

It is with great sentiment and appreciation that I write this tribute to Julian Müller. My understanding of facilitation would have been much thinner had the story of his theoretical development taken another route.

To a large degree, mine is a work of translation and of practical theological facilitative praxis: translation from, not only the usual concerns in practical and pastoral theology, but also the kind of epistemology that characterises Müller's work, and translation to the public, organisational context with the imperative of practice participation through modalities such as facilitation, coaching, consulting and research. In this act of translation, I have found that PTF places on the table again the aspects of who we are and what we do as practical theologians. These questions cannot be answered from one perspective. For the practical theological facilitator, however, to facilitate is what one does as a lecturer and as a researcher, as a therapist, as a coach, and therefore also in one's public professional capacity (such as in organisations).

Focusing on the role of the person of the practical theological facilitator, is to my mind, one of the boldest steps to clarify what the practical theologian does within a particular practical theological tradition and within the broader tradition of 'practical wisdom' (cf. Browning 1991; Müller 1994b). There is still much to do, but thankfully the personal and conceptual journeys that Julian Müller went through adds meaningfully to the development of my own story and journey with practical theology, towards practical theological facilitation.

\section{Acknowledgements Competing interests}

The author declares that he has no financial or personal relationship(s) that may have inappropriately influenced him in writing this article.

\section{References}

Arbnor, I. \& Bjerke, B., 2009, Methodology for creating business knowledge, 3rd edn., Sage, London.

Bens, I., 2005, Facilitating with ease. Core skills for facilitators, team leaders and members, managers, consultants, and trainers, 2nd edn., Jossey-Bass, San Francisco. PMCid:PMC1665473

Berger, P. \& Luckmann, T., 1966, The social construction of reality, Doubleday, New York.

Brammer, L.M., 1979, The helping relationship. Process and skills, 2nd edn., PrenticeHall, Upper Saddle River.

Browning, D.S., 1991, A fundamental practical theology. Descriptive and strategic proposals, Fortress Press, Minneapolis.

Burr, V., 2003, Social constructionism, 2nd edn., Routledge, New York.

Burtonshaw-Gunn, S.A., 2010, Essential tools for management consulting. Tools, models and approaches for clients and consultants, Wiley, West Sussex.

Cope, M., 2010, The seven C's of consulting, 3rd edn., Pearson, Harlow.
Crites, S., 1971, 'The narrative quality of experience', Journal of the American Academy of Religion 39(3), 291-311. http://dx.doi.org/10.1093/jaarel/XXXIX.3.291

Demasure, K. \& Müller, J., 2006, 'Perspectives in support of the narrative turn in pastoral care', Nederduitse Gereformeerde Teologiese Tydskrif 47(3\&4), 410-419.

Drennon, C.E. \& Cervero, R.M., 2002, 'The politics of facilitation in practitioner inquiry groups', Adult Education Quarterly 53(3), 193-209. http://dx.doi. org/10.1177/0741713602052003003

Egan, G., 2013, A problem-management and opportunity-development approach to helping, 10th edn., Brooks/Cole, Pacific Grove.

Ellis, C. \& Bochner, A.P. (eds.), 1996, Composing ethnography: Alternative forms of qualitative writing, Sage Publications, Walnut Creek.

Freedman, J. \& Combs, G., 1996, Narrative therapy: The social construction of preferred realities, W.W. Norton and Company, New York.

Gergen, K.J., 1999, An invitation to social construction, Sage, London.

Gerkin, C.V., 1986, Widening the horizons. Pastoral responses to a fragmented society, Westminster Press, Philadelphia. PMid:3729110

Grözinger, A., 2012, 'Risky freedoms - Protestantism and life-story', in D. Human \& D. Veldsman (eds.), Oor jou afdrukke. Met waardering vir Cas Vos se teolgoiespoëtiese bydrae, pp. 39-50, Universiteit van Pretoria, Pretoria.

Harsch-Porter, S., 2011, 'Social constructionism', in J. Wildflower \& D. Brennan (eds.), The handbook of knowledge-based coaching. From theory to practice, pp. 81-88, Jossey-Bass, San Francisco.

Hiemstra, R., 2012, Being and effective facilitator, viewed 02 May 2013, from http:// www-distance.syr.edu/facilita.htm

Holstein, J.A. \& Gubrium, J.F. (eds.), 2008, Handbook of constructionist research, Guilford Publications, New York.

Human, L.H., Liebenberg, J. \& Müller, J.C., 2001, 'Morality, imagination, and human decision making', Verbum et Ecclesia 22(2), 300-313. http://dx.doi.org/10.4102/ ve.v22i 2.648

Hunter, D., Thorpe, S., Brown, H. \& Bailey, A., 2007, The art of facilitation: The essentials for leading great meetings and creating group synergy, Jossey-Bass, San Francisco. http://dx.doi.org/10.1057/palgrave.ijea.2150074

Johnstone, B., 2008, Discourse analysis, 2nd edn., Blackwell Publishing, Oxford.

Kashtan, M., 2005, 'The gift of self: The art of transparent facilitation', in S. Schuman (ed.), The IAF handbook of group facilitation, pp. 573-590, Jossey-Bass, San Francisco.

Keith, D.V. \& Whitaker, C.A., 1988, Family transitions, Guilford Press, New York.

Kirk, P. \& Broussine, M., 2000, 'The politics of facilitation', Journal of Workplace Learning: Employee Counseling Today 12(1), 13-22. http://dx.doi. Learning: Employee Counseling

Lester, A.D., 1995, Hope in pastoral care and counselling, Westminster/John Knox Press, Louisville.

Louw, N.A. \& Müller, J.C., 2002, 'Om verbeeldingryk te lewe: Verbeelding in die pastorale narratiewe terapie en die teologie van Watler Brueggemann HTS Teologiese Studies/Theological Studies 58(1), 340-354. http://dx.doi. org/10.4102/hts.v58i1.546

Morgan, A., 2000, What is narrative therapy? An easy to read introduction, Dulwich Centre Publications, Adelaide.

Morgan, G., 2006, Images of organization, Sage, Thousand Oaks.

Müller, J.C., 1994a, 'Intercultural pastoral care. An Eco-hermeneutical perspective', Skrif en Kerk 15(1), 345-357.

Müller, J.C., 1994b, 'Practical theological wisdom in the context of pastoral marriage and family therapy', Practical theology in South Africa 9(1), 20-28.

Müller, J.C., 1996, Om tot verhaal te kom: Pastorale gesinsterapie, RGN-studies in Praktiese Teologie, RGN Uitgewery, Pretoria.

Müller, J.C., 2000, Reis-geselskap. Die kuns van narratiewe pastorale gesprekvoering, Luxverbi, Wellington

Müller, J.C., 2003, 'Unheard stories of people infected and affected by HIV/Aids about care and the lack of care: The research story of the project', Practical Theology in South Africa 18(3), 1-20.

Müller, J.C., 2004, 'HIV/AIDS, narrative practical theology, and postfoundationalism: The emergence of a new story', HTS Teologiese Studies/Theological Studies 60(1\&2), 293-306

Müller, J.C., 2005, 'A postfoundationalist, HIV-positive practical theology', Practical Theology in South Africa 20(2), 72-88.

Müller, J.C., 2009, 'Transversal rationality as a practical way of doing interdisciplinary work, with HIV and Aids as a case study', Practical Theology in South Africa 24(2), 199-228.

Müller, J.C., 2011a, 'Postfoundational practical theology for a time of transition', HTS Teologiese Studies/Theological Studies 67(1), Art. \#837, 5 pages. http://dx.doi. org/10.4102/hts.v67i1.837

Müller, J.C., 2011b, '(Outo)biografie as teologie', HTS Teologiese Studies/ Theological Studies 67(3), Art. \#1113, 5 pages. http://dx.doi.org/10.4102/hts.v67i3.1113

Müller, J.C., 2011c, Om te mag twyfel, Tafelberg, Cape Town.

Müller, J.C., 2012a, 'Transversaliteit as oriëntasiepunt vir die waarneem van die Prakties-Teologiese landskap', in D. Human \& D. Veldsman (reds.), Oor jou afdrukke. Met waardering vir Cas Vos se teolgoies-poëtiese bydrae, bl. 95-105, Universiteit van Pretoria, Pretoria.

Müller, J.C., 2012b, '(Practical) Theology: A story of doubt and imagination', UP Expert Lecture Series, University of Pretoria, Pretoria, 05 September 2012. 
Müller, J.C. \& Pienaar, H.E., 2003, 'A social-constructionist, narrative understanding of the Church's morality on sex', Verbum et Ecclesia 24(1), 137-155.

Müller, J.C. \& Schoeman, K., 2004, 'Narrative research: A respectful and fragile intervention', Sociale Interventie 13(3), 7-13.

Müller, J.C. \& Stone, H.W., 1998, 'Intercultural pastoral care and counselling: Resources from narrative therapy and brief pastoral counseling', Skrif en Kerk 19(2), 325-341.

Müller, J.C., Van Deventer, W. \& Human, L.H., 2001, 'Fiction writing as metaphor for research: A narrative approach', Practical Theology in South Africa 16, 76-96.

Nash, R.J., 2001, 'Constructing a spirituality of teaching: A personal perspective', Religion and Education 28(1), 1-20. http://dx.doi.org/10.1080/15507394.2001. 10012271

Nash, R.J., 2004, Liberating scholarly writing: The power of personal narrative, Teachers College Press, New York.

Niehbur, H.R., 1963, The responsible self: An essay in Christian moral philosophy, Harper, New York.

Oliver, K.L., 1998, 'A journey into narrative analysis: A methodology for discovering meanings', Journal of Teaching in Physical Education 17, 244-259.

Pienaar, H.E., 2005, 'An explorative study on the interaction between the arts and narrative practice', PhD thesis, Department of Practical Theology, University of Pretoria.

Pienaar, H.E., 2012, 'Overture to practical theological facilitation', Nederduitse Gereformeerde Teologiese Tydskrif 53(3\&4), 241-255.
Pienaar, H.E. \& Müller, J.C., 2012, 'The practical theologian as decentred but influential facilitator', HTS Teologiese Studies/Theological Studies 68(2), 1-10. Art. \#1307. http://dx.doi.org/10.4102/hts.v68i2.1307

Roesler, C., 2006, 'A narratological methodology for identifying archetypical story patterns in autobiographical narratives', Journal of Analytical Psychology 52, 574-586.

Rosenbaum, R. \& Dyckman, J., 1995, 'Integrating self and system: An empty intersection?', Family Process 34, 21-41.

Sternberg, R.J., 2001, Psychology. In search of the human mind, 3rd edn., Harcourt, Philadelphia.

Thomas, G., 2010, 'Facilitator, teacher, or leader? Managing conflicting roles in outdoor education', Journal of Experiential Education 32(3), 239-254. http:// dx.doi.org/10.5193/JEE.32.3.239

Van den Berg, J.A. \& De Wet, R., 2008, 'Sketse van 'n Pastoraat van Narratiewe Betrokkenheid in die Lukasevangelie met besondere klem op die Saggeusverhaal', In die Skriflig 42(1), 145-157.

Van Huyssteen, J.W., 1997, Essays in postfoundationalist theology, Eerdmans, Grand Rapids.

Van Huyssteen, J.W., 2000, 'Postfoundationalism and interdisciplinarity. A response to Jerome Stone', Zygon 35(2), 427-439. http://dx.doi.org/10.1111/05912385.00285

Van Huyssteen, J.W., 2006, 'When our bodies do the thinking: Theology and science converge', American Journal of Theology \& Philosophy 27(2), 127-153.

White, M. \& Epston, D., 1990, Narrative means to therapeutic ends, W.W. Norton \& Company, London. 